\title{
„Tempus fugit, venit mors” \\ a streptococcalis toxikus sokk szindrómáról egy eset kapcsán
}

\author{
Szabó Bálint Gergely dr. ${ }^{1,2,3}$. Kiss Rebeka dr. ${ }^{3,4}$ \\ Lénárt Katalin Szidónia dr. ${ }^{1,3}$ - Radka Nikolova dr. ${ }^{5}$ - Kádár Béla dr. ${ }^{5,6,7}$ \\ ${ }^{1}$ Dél-pesti Centrumkórház, Országos Hematológiai és Infektológiai Intézet, Infektológiai Osztály, Budapest \\ ${ }^{2}$ Semmelweis Egyetem, Klinikai Orvostudományok Doktori Iskola, Budapest \\ ${ }^{3}$ Semmelweis Egyetem, Általános Orvostudományi Kar, Infektológus szakorvosképzés, Budapest \\ ${ }^{4}$ Markhot Ferenc Oktatókórház és Rendelőintézet, Eger \\ ${ }^{5}$ Dél-pesti Centrumkórház, Országos Hematológiai és Infektológiai Intézet, \\ Központi Laboratórium, Mikrobiológiai Profil, Budapest \\ ${ }^{6}$ Semmelweis Egyetem, Általános Orvostudományi Kar, Orvosi Mikrobiológiai Intézet, Budapest \\ ${ }^{7}$ Semmelweis Egyetem, Általános Orvostudományi Kar, Orvosi mikrobiológus szakorvosképzés, Budapest
}

\begin{abstract}
A streptococcalis toxikus sokk szindróma hiperakut, életet veszélyeztető betegség, invazív (a leggyakrabban A-, kisebb arányban B-, G- és C-csoportú) Streptococcus-fertőzés szövődménye. A bevezető tünetek - láz, influenzára emlékeztető panaszok és a hipotenzió - szegényesek és aspecifikusak. A betegség gyors progressziója és rossz prognózisa miatt a diagnosztika feltétele a gyakran jellegtelen tünettanra (néha csupán láz és sokkállapot) támaszkodó korai klinikai gyanú. Az ellátás hárompillérú - antistreptococcalis terápia (és bizonyos esetekben intravénás immunglobulin) mellett a kórképhez társuló sokszervi elégtelenség intenzív szupportációja, valamint az infektív góc radikális sebészi megoldása elengedhetetlen. Közleményünkben infekciós góc nélküli (primer) $S$. pyogenes bacteriaemiához társuló streptococcalis toxikus sokk szindrómában meghalt betegünk esetét mutatjuk be, és összefoglaljuk a kórképpel kapcsolatos legfőbb irodalmi ismereteket.

Orv Hetil. 2019; 160(48): 1887-1893.
\end{abstract}

Kulcsszavak: Streptococcus pyogenes, toxikus sokk szindróma, szuperantigén, fertőzés

\section{“Tempus fugit, venit mors" - about streptococcal toxic shock syndrome:} a case report and mini-review

Streptococcal toxic shock syndrome (STSS) is a hyperacute, life-threatening illness, a complication of invasive streptococcal (mostly group A, rarely groups B, G or C) infection. There is no portal of entry (skin, vagina, pharynx) in nearly half of the STSS cases. The initial signs and symptoms (fever, flu-like complaints, hypotension) are scarce and aspecific, but because of its rapid progression and poor prognosis, early high level of suspicion is necessary. Management has 3 crucial points: initiation of anti-streptococcal regimen (and intravenous immunoglobulin in some cases), aggressive intensive care support of multi-organ failure, and surgical control of the infective source. In this article, we present a case of a patient succumbing to streptococcal toxic shock syndrome which was preceded by primary S. pyogenes bacteremia, and review the key points of this potentially fatal disease for practising clinicians.

Keywords: Streptococcus pyogenes, toxic shock syndrome, superantigen, infection

Szabó BG, Kiss R, Lénárt KSz, Nikolova R, Kádár B. [ “Tempus fugit, venit mors” - about streptococcal toxic shock syndrome: a case report and mini-review]. Orv Hetil. 2019; 160(48): 1887-1893.

(Beérkezett: 2019. július 24.; elfogadva: 2019. augusztus 19.) 


\section{Rövidítések}

$\mathrm{CDC}=($ Centers for Disease Control and Prevention $)$ amerikai Járványügyi és Betegségmegelőzési Központ; $\mathrm{CK}$ = citokeratin; $\mathrm{CRP}=\mathrm{C}$-reaktív protein; $\mathrm{CT}=($ computed tomography $)$ számítógépes tomográfia; DIC = (disseminated intravascular coagulation) disszeminált intravascularis coagulatio; GOT = glutamát-oxálacetát-transzamináz; HIV = (human immunodeficiency virus) emberi immunhiányt előidéző vírus; IDSA = (Infectious Diseases Society of America) Amerikai Infektológiai Társaság; IVIG = intravénás immunglobulin; $\mathrm{LDH}=$ laktátdehidrogenáz; $\mathrm{NE}=$ nemzetközi egység; NSAID $=($ nonste roidal antiinflammatory drug) nemszteroid gyulladáscsökkentó gyógyszer; $\mathrm{PCR}=($ polymerase chain reaction $)$ polimeráz-láncreakció; $\mathrm{SBO}=$ sürgősségi betegellátó osztály; STSS = (streptococcal toxic shock syndrome) streptococcalis toxikus sokk szindróma; TSS $=($ toxic shock syndrome $)$ toxikus sokk szindróma

Hazánkban kevés számú, baktérium által okozott fertőzés képes hiperakut kezdettel és kórlefolyással, vagyis $\leq 24$ óra alatt immunkompetens egyént a halálához vezetni. A gyakoribb kórképek közé a Neisseria meningitidis és a Streptococcus pneumoniae által előidézett invazív betegségek, a Leptospira interrogans okozta leptospirosis, valamint a Staphylococcus aureus vagy a Streptococcus pyogenes által okozott invazív kórképek és toxikus sokk szindrómák tartoznak [1].

A streptococcalis toxikus sokk szindróma (STSS) olyan, toxin mediálta kórállapot, mely önálló entitásként vagy invazív $S$. pyogenes-fertőzések komplikációjaként lép fel, és rövid idő alatt sokszervi elégtelenséghez vezethet. Az első esetsorozatot 1987-ben közölték „toxikus sokkszerű szindróma" néven, mivel klinikai lefolyása hasonlított az akkoriban már ismert staphylococcalis toxikus sokk szindrómáéhoz, de a kórokozó eltérônek bizonyult [2].

A STSS kimenetelét a $S$. pyogenes virulenciája, az immunrendszert hiperaktiváló streptococcalis exotoxinok és az egyéb bakteriális exoenzimek jelenléte, valamint a gazdaszervezet antiinfektív válaszkészségének kölcsönhatása határozza meg. Korai intenzív osztályos ellátás, valamint azonosítható góc esetén agresszív sebészi intervenció nélkül a kórkép mortalitása még adekvát antibiotikumterápia mellett is magas [3]. A közleményben bemutatjuk egy STSS-ben elhunyt betegünk kórtörténetét, valamint röviden áttekintjük a témakörrel kapcsolatos legfőbb tudnivalókat.

\section{Esetbemutatás}

A 63 éves, essentialis hypertonia miatt kezelt férfi beteget egy októberi hétvégén, hajnalban hidegrázás, majd $40{ }^{\circ} \mathrm{C}$-os láz és hasmenéses székürítés ébresztette álmából. A területi illetékességú sürgősségi betegellátó osztályon (SBO) jelentkezett, ahonnan akut bakteriális gastroenteritis iránydiagnózisával centrumunkba irányították. $\mathrm{Az}$ asztalosként dolgozó beteg rendezett lakókörülmé- nyek között élt feleségével, környezetében hasonló betegségben szenvedőről nem tudott. Felderíthető állatexpozíció vagy gyermekkontakt nem volt, kórházban nem feküdt. A betegsége előtti hetekben többször ment a lakhelyéhez közeli tóhoz horgászni, és hobbiszinten tevékenykedett konyhakertjében. Az alkohol, dohánytermék és drog használatát negálta.

A sürgősségi osztályon a fizikális vizsgálat során magas lázat $\left(39,5^{\circ} \mathrm{C}\right)$, mérsékelt hipotenziót $(110 / 60 \mathrm{Hgmm})$, diffúz hasi nyomásérzékenységet rögzítettek. Laboratóriumi vizsgálata kisfokú leukocytosist, thrombopeniát, hypocalcaemiát, azotaemiát és CRP-elevációt igazolt (1. táblázat). Kétirányú mellkasi és natív hasi röntgenfelvétel, valamint hasi ultrahangvizsgálat készült negatív eredménnyel. Mikrobiológiai vizsgálatot nem kezdeményeztek. A SBO-n a beteg parenteralis folyadék- és ionpótlásban, intravénás lázcsillapításban és görcsoldó kezelésben részesült. Átvételéig számos alkalommal ürített híg, normochol székleteket, ez osztályunkon is folytató-

1. táblázat |A beteg laboreltérései a sürgősségi osztályon és kontrollvizsgálatakor

\begin{tabular}{|c|c|c|c|}
\hline Laborparaméter & $\begin{array}{l}\text { Normáltar- } \\
\text { tomány }\end{array}$ & $\begin{array}{l}\text { Értékek } \\
\text { a SBO-n }\end{array}$ & $\begin{array}{c}\text { Értékek } \\
\text { az osztályon }{ }^{2}\end{array}$ \\
\hline Fehérvérsejtszám $\left(\times 10^{9} / 1\right)$ & $5-10$ & 12,1 & 1,91 \\
\hline Hemoglobin $(\mathrm{g} / \mathrm{l})$ & $125-175$ & 145 & 157 \\
\hline Vérlemezkeszám $\left(\times 10^{9} / 1\right)$ & $150-400$ & 97 & 34 \\
\hline Nátrium (mmol/l) & $135-145$ & 138 & 139 \\
\hline Kálium (mmol/1) & $3,5-5,1$ & 4,6 & 4,2 \\
\hline Kalcium (mmol/1) & $2,2-2,6$ & 1,93 & 1,88 \\
\hline GOT (IU/1) & $5-55$ & 52 & 149 \\
\hline GPT (IU/1) & $5-55$ & 48 & 76 \\
\hline GGT (IU/1) & $6-60$ & 72 & 92 \\
\hline $\operatorname{ALP}(\mathrm{IU} / 1)$ & $95-364$ & 98 & 106 \\
\hline $\mathrm{LDH}(\mathrm{IU} / 1)$ & $153-463$ & 325 & 847 \\
\hline $\mathrm{CK}(\mathrm{IU} / \mathrm{l})$ & $15-170$ & n.a. & 2594 \\
\hline Karbamid (mmol/l) & $3,5-10$ & 12 & 23 \\
\hline Kreatinin $(\mu \mathrm{mol} / 1)$ & $90-120$ & 180 & 279 \\
\hline $\mathrm{CRP}(\mathrm{mg} / \mathrm{l})$ & $<10$ & 37 & 436 \\
\hline Prokalcitonin (ng/ml) & $0,05-0,5$ & n.a. & 139 \\
\hline Laktát (mmol/1) & $0,5-2$ & n.a. & 10,8 \\
\hline Vércukor (mmol/1) & $3,5-5,5$ & 4,6 & 8,6 \\
\hline INR (dimenzió nélkül) & $0,8-1,2$ & n.a. & 1,72 \\
\hline aPTI (s) & $35-45$ & n.a. & 62 \\
\hline
\end{tabular}

${ }^{1}$ A panaszok kezdete után kb. 4 órával készült laboreredmény.

${ }^{2} \mathrm{~A}$ panaszok kezdete után kb. 12 órával készült laboreredmény.

ALP = alkalikus foszfatáz; aPTI = aktivált parciális tromboplasztinidő; $\mathrm{CK}=$ kreatin-kináz; CRP $=$ C-reaktív protein; GGT = gamma-glutamil-transzferáz; GPT = glutamát-piruvát-transzamináz; INR = véralvadásmérés; $\mathrm{LDH}=$ laktátdehidrogenáz; n.a. = nincs adat; $\mathrm{SBO}=$ sürgősségi betegellátó osztály 
dott. Hányinger, hányás nem jelentkezett. Az átvevő intézetben az ügyeletes orvos ismételt fizikális vizsgálat során normotenzív állapotot talált, a hasi nyomásérzékenység és a láz középmagas szinten perzisztált $\left(38,3^{\circ} \mathrm{C}\right)$, valamint új tünetként palpációval provokálható enyhe, alsó végtagi, proximális izomfájdalmat talált. A beteg a közérzetét javulónak mondta. Az elfogadható általános állapotra való tekintettel az áthelyezéskor feltüntetett akut bakteriális gastroenteritis diagnózisával egyetértve folytattuk a folyadék- és ionpótlást, antipiretikummal, spazmolitikummal kiegészítve. Obszervációnk kezdetekor, láz alatt hemokultúrákat, széklettenyésztést kezdeményeztünk, valamint a beteg laboratóriumi vizsgálatait ismételtük. A vérminta a laboratórium értesítése alapján hemolizált. A beteg összességében kielégítő, stabil állapota alapján az ismételt vérvételtől eltekintettünk.

$\mathrm{Az}$ átvételt követő 6 órában az alkalmazott terápia mellett a beteg közérzete tovább javult, testhőmérséklete $37,6{ }^{\circ} \mathrm{C}$-ig csillapodott, bár hasmenése és izomfájdalma nem szűnt. Az ismételt orvosi vizit során új tünetként a beteg által nem észlelt kétoldali conjunctivalis belövelltséget, tachycardia nélküli mérsékelt vérnyomáscsökkenést (110/60 Hgmm) rögzítettek. A következő órában a betegnél szótalálási nehézséggel, parciális dezorientáltsággal kísért tudatzavar lépett fel a vigilitas megtartottsága mellett, egyéb neurológiai eltérés nélkül. A korábban jelzett izomfájdalomnak megfelelő lokalizációban halvány, szimmetrikus bőrpír jelentkezett, behatolási kapu nem vált láthatóvá. A diagnózist újraértékelve ismeretlen fókuszú szepszist véleményeztünk, a laboratóriumi vizsgálatokat sürgősséggel megismételtük; a parenteralis folyadékpótlást nagy volumenű krisztalloid-, majd zselatinoldat bevezetésével folytattuk, empirikusan ceftriaxonkezelést indítottunk, s hólyagkatétert vezettünk fel. Az addig megismert epidemiológiai és klinikai adatok alapján elsősorban a leptospirosis és a fulmináns Gram-negatív szepszis, az invazív Salmonella-betegség lehetősége merült fel. A leletek ekkor már sokszervi elégtelenségnek megfelelő eltéréseket tükröztek (1. táblázat). Terápiánk ellenére a beteg állapota rohamosan romlott, hipotenziója fokozódott, tachycardia és nehézlégzés alakult ki, tudati hozzáférhetősége csökkent. Az intenzív osztályos konzílium az instabil hemodinamika és légzésmechanika miatt az azonnali átvétel mellett döntött. Helyszíni szedációt és endotrachealis intubációt követően a beteget intenzív osztályunkra helyeztük, ahol gépi lélegeztetést, presszoramin-terápiát kezdtek, és antiinfektív kezelését meropenemmel egészítették ki. Az intenzív terápiás törekvések ellenére a beteg a sürgősségi osztályos ellátásától számítva 12 óra alatt elhunyt.

Másnap délután a beteg valamennyi, osztályunkon levett hemokultúrájának kenetében Gram-pozitív rövid coccusláncokat láttak. A baktériumot később $S$. pyogenesként identifikálták. Az intenzív osztályon megismételt hemokultúrái nem jeleztek, később sterilnek adták ki óket. Rutin-széklettenyésztése a leggyakoribb enteropatogének (Salmonella, Shigella, Yersinia, Campylobacter sp.) irányában negatív lett. A beteg sectiója során a lezajlott szepszisnek megfeleltethető makroszkópos szervi eltéréseket találtak. A $S$. pyogenes-törzset az Országos Epidemiológiai Központba továbbították, ahol génspecifikus PCR-vizsgálattal az izolátum pirogén exotoxin $\mathrm{C}$ $(s p e C)$-termelőnek bizonyult.

\section{Megbeszélés}

\section{Az eset diszkussziója}

A beteget a klinikai és a mikrobiológiai adatok alapján toxikus sokk szindrómával szövődő primer $S$. pyogenes bacteriaemiában veszítettük el. A Gram-pozitív, aerob coccusok közé tartozó baktérium számos virulenciafaktort termelhet, ezek felelnek a magas szintü humán patogenitásért (2. táblázat). A pirogén exotoxin $\mathrm{C}$ és $\mathrm{A}$ a baktériumra specifikus ún. szuperantigén, a toxikus sokk szindróma patogenezisének kulcsmolekulája. Megjegyzendő, hogy nem minden $S$. pyogenes-törzs képes szuperantigének szintézisére vagy felszabadítására. A szuperantigének in vivo szintézise polyclonalis lymphocytaaktivációhoz, következményes proinflammatoricus citokinviharhoz, ez pedig többszervi elégtelenséghez, halálhoz

\section{2. táblázat A Streptococcus pyogenes legfőbb virulenciafaktorai}

\begin{tabular}{|c|c|c|}
\hline $\begin{array}{l}\text { A virulenciafaktor } \\
\text { elhelyezkedése }\end{array}$ & Virulenciafaktor & A virulenciafaktor funkciója \\
\hline \multirow{6}{*}{$\begin{array}{l}\text { Sejtfelszínhez } \\
\text { kötött }\end{array}$} & Bakteriális tok & A fagocitózis gátlása \\
\hline & M-protein & $\begin{array}{l}\text { Opszonizáció, fagocitózis } \\
\text { gátlása }\end{array}$ \\
\hline & F-protein & Sejtadhézió \\
\hline & Lipoteikolsav & $\begin{array}{l}\text { Sejtadhézió, TLR-depen- } \\
\text { dens sejtaktiváció }\end{array}$ \\
\hline & Adhezinek & Sejtadhézió \\
\hline & C5a peptidáz & $\begin{array}{l}\text { Neutrofilek kemotaxisának } \\
\text { gátlása a C5a bontásával }\end{array}$ \\
\hline \multirow[t]{4}{*}{ Exoenzim } & Sztreptokináz & Plazminogénaktivátor \\
\hline & Sztreptodornáz & $\begin{array}{l}\text { DNáz, a neutrofil } \\
\text { extracelluláris csapdák } \\
\text { bontása }\end{array}$ \\
\hline & Hialuronidáz & $\begin{array}{l}\text { A kötőszöveti hialuronsav } \\
\text { bontása }\end{array}$ \\
\hline & Kemokin-proteázok & $\begin{array}{l}\text { Neutrofilek kemotaxisának } \\
\text { gátlása az IL8 bontásával }\end{array}$ \\
\hline \multirow[t]{4}{*}{ Exotoxin } & $\begin{array}{l}\text { Sztreptolizinek } \\
(\mathrm{O}, \mathrm{S})\end{array}$ & $\begin{array}{l}\text { Hemolízis, neutrofilek és } \\
\text { thrombocyták károsítása }\end{array}$ \\
\hline & Pirogén exotoxin A & $\begin{array}{l}\text { Szuperantigén, a TSS } \\
\text { klinikumáért felel }\end{array}$ \\
\hline & Pirogén exotoxin B & $\begin{array}{l}\text { Szuperantigén, a skarlát } \\
\text { klinikumáért felel }\end{array}$ \\
\hline & Pirogén exotoxin C & $\begin{array}{l}\text { Szuperantigén, a TSS } \\
\text { klinikumáért felel }\end{array}$ \\
\hline
\end{tabular}

TLR = Toll-szerű receptor; TSS = toxikus sokk szindróma 
vezet. A betegség gyors lefolyását Horatius klasszikus szavaival jellemezhetjük a legjobban: „tempus fugit, venit mors”, vagyis „gyorsan telik az idő, észre sem vesszük, és már itt a halál”.

Betegünk esetében differenciáldiagnosztikai szempontból elsősorban a leptospirosis, illetve a Gram-negatív szepszis lehetősége merült fel. A leptospirosis gyanúját látszott erósíteni a pozitív expozíciós anamnézis (horgászás állóvízben, illetve annak közelében), a típusos lappangási idő (10-21 nap), a hirtelen kezdetű, hidegrázással kísért magas láz, a kifejezett izomfájdalom, a hasi tünetek dominanciája, valamint a kétoldali conjunctivitis. A leptospirosis diagnózisa ellen szólhat a pár óra alatt kialakult delírium, valamint a fejfájás hiánya. A gastrointestinalis tünetek dominanciája és a közösségi kezdet alapján Gram-negatív - elsősorban Salmonella sp. okozta - szepszis és invázió mellett szólt volna a hipotonizálódás gyors üteme, az akut légzési elégtelenség kialakulása; a Gram-negatív véráram-infekció ellen hozható fel az erre hajlamosító tényezők hiánya (például agg életkor, diabetes mellitus, máj- vagy veseelégtelenség, poszttranszplantációs vagy súlyos immunszupprimált állapot, HIV-fertőzés stb.).

A pontos diagnózist a STSS-re jellemző bőrlaesio korai hiánya, valamint a nem észrevehető fertőzési kapu késleltethette. Az utóbbi lehetett a munkavégzés vagy kertészkedés során szerzett mikrotrauma. További tanulság, hogy az első vérvizsgálat leletét „hemolizált minta”ként adta ki a labor, mely a keringő bakteriális hemolizinek szerepére is utalhat, mivel ezek jelenléte a vérben in vitro értékelhetetlenné teszi a mintát. A hatékony antistreptococcalis kezelés megkezdése után ismételt hemokultúrák sterilnek bizonyultak, a bacteriaemia egy dózis antibiotikum után megszűnt. Ezt a jelenséget és a betegség klinikai progresszióját az antibiotikummal nem befolyásolható toxinhatás magyarázza.

\section{A STSS epidemiológiai jellemzöi és klinikai képe}

A STSS ritka betegség, mely minden életkorban előfordulhat. Jellemzően sporadikus megjelenésű, de leírtak járványszerü esethalmozódásokat bölcsődékben, családokban és idősotthonokban is. Egy prospektív, európai populációs szintû adatokat feldolgozó vizsgálat eredményei szerint az invazív $S$. pyogenes-fertőzés becsült incidenciája évi 3/100 000 lakos körüli [4]. A STSS origója lehet akut tonsillopharyngitis, bőr-lágyrész infekció, valamint post partum endometritis is; az esetek egyharmada invazív betegséghez kötődik. Bőr-lágyrész érintettség intakt szövetben, mütéti sebinfekció vagy trauma talaján is felléphet. Irodalmi adatok alapján az esetek 50\%-ában a primer fertőzési kapu klinikailag nem igazolódik, ebbe a csoportba típusosan a 40-60 éves, korábban egészséges férfi betegek tartoznak. Az invazív $S$. pyogenes-betegségre és különösképpen a STSS-re rizikóállapotot jelent a krónikus alkoholfogyasztás és májbetegség, a súlyos immunszupprimált állapotok, az intravénás droghaszná- lat, a cellulitisszel szövődött varicella, a cukorbetegség és a szülés. Nem egyértelmú az ok-okozati kapcsolat a STSS és a nemszteroid gyulladáscsökkentők (NSAID) szedése között, de feltehetően az immunrendszert érintő pleiotrop hatásuk miatt ezek a gyógyszerek hozzájárulhatnak a kórállapot kialakulásához és progressziójához $[5,6]$.

A STSS korai jellegzetességei a látványhoz viszonyított aránytalanul nagy, spontán vagy allodyniás ${ }^{1}$ lágyszöveti és izomfájdalom (hyperalgesia) és a diffúzzá váló macularis bőrpír, bár az utóbbi hozzávetőleg csak minden tizedik betegnél jelenik meg (3. táblázat). Az erős fájdalom kiterjedése meghaladja a szemmel látható bőrelváltozás terjedelmét. A korai tüneteket influenzaszerú panaszok (fejfájás, kifejezett gyengeség) vezethetik be. A bőrérintettség mindig felveti a mélyszövetekben kezdődő vagy zajló invázió (myositis, nekrotizáló fasciitis) lehetőségét is. A betegség előrehaladásával hidegrázással kísért magas láz és aspecifikus gastrointestinalis tünetek (hányinger-hányás, hasmenés, hasi fájdalom) mutatkoznak. A STSS végstádiumát jelentő többszervi elégtelenség része az akár hirtelen kezdetü hipotenzió és légzési distressz, tudatzavar, akut vese- és májelégtelenség, coagulopathia és esetleg a lágyrész-nekrózis kialakulása. $\mathrm{Az}$ invazív streptococcalis betegségek dinamikája miatt az egyes klinikai entitások egymásba progrediálhatnak, így például a STSS kezeletlenül nekrotizáló fasciitisbe mehet át $[3,7,8]$.

\section{A STSS diagnosztikája}

A kezdeti fizikális és laboratóriumi vizsgálati eredmények gyakran nem orientálják kellően a vizsgáló orvost, a status a kórlefolyás elején olykor csak ennyi: láz és hipotenzió. A STSS diagnózisának megállapításához a Centers for Disease Control and Prevention (CDC) 2010-ben megújított kritériumrendszerét érdemes használni (3. táblázat). Ennek alapján valószínü STSS-ről beszélünk, ha a kritériumok alapján a klinikai esetdefiníció teljesül, az eltérések hátterében más etiológia nem igazolódik, és nem steril helyről vett mintából $S$. pyogenes izolálható. Igazolt STSS-ról beszélhetünk, ha a klinikai esetdefiníció teljesül, és fiziológiásan steril helyről származó mintából $S$. pyogenes tenyészik. Hemokultúrák - és a klinikum által vezérelten - egyéb releváns mikrobiológiai minták (például bőrlaesio, sebkörnyék, mélyszövet, ascites, pleuralis fluidum, synovium, vizelet, torokváladék, lochia, hüvelyváladék stb.) vétele tehát kötelező, a laboratóriumi kérőlapon fontos a STSS gyanújának feltüntetése. A S. pyogenes (A-csoportú Streptococcus) mellett ritkán a B-, C- és G-csoportú Streptococcusok is képesek STSS kiváltására, az etiológiai háttér pusztán a klinikai kép alapján biztonsággal nem differenciálható. Az esetek mindegy 50\%-ában a hemokultúrák 24 órán

Nem fájdalmas taktilis ingerre bekövetkező kóros fájdalomérzet. 
A streptococcalis toxikus sokk szindróma alarmírozó klinikai je lei, valamint a Centers for Disease Control and Prevention (CDC) 2010-ben megújított felnőttkori diagnosztikus kritériumai és esetklasszifikációja

\section{STSS-re alarmírozó klinikai jelek}

Megelőző penetráló lágyszöveti trauma, műtét vagy

NSAID-használat

Hirtelen kezdetû magas láz, hidegrázás

Hasi panaszok (hányás, hasmenés, hasi fájdalom)

Aránytalanul nagy vagy allodyniás lágyszöveti fájdalom

Generalizált bőrkiütés jelenléte

Bőr-lágyrész infekció klinikai jelei

Akut kezdetű, progresszív többszervi elégtelenség

Diagnosztikus kritériumok (CDC, 2010)

I. Klinikai kritériumok (az 1-2. pontoknak egyszerre kell teljesülniük)

1. Artériás hipotenzió Szisztolés vérnyomás $\leq 90 \mathrm{Hgmm}$

2. Többszervi

elégtelenség (min. 2): Progresszív légúti tünetekkel, diffúz

Akut légzési distressz

szindróma

kétoldali tüdőinfiltrátumokkal és hypoxaemiával $\left(\mathrm{PaO}_{2} / \mathrm{FiO}_{2} \leq 300 \mathrm{Hgmm}\right)$ járó akut (noxától számított 1 héten belül) állapot, szívelégtelenség vagy diffúz kapillárisleak hiányában

Májérintettség

A normáltartomány felső határánál vagy ismert májbetegség esetén a kiindulási értékhez képest $\geq 2 \times$ magasabb szérumGPT-, GOT- vagy -összbilirubinszint

Veseérintettség

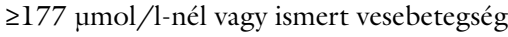
esetén a kiindulási értékhez képest $\geq 2 \times$ magasabb szérum-kreatininszint

Coagulopathia

Vérlemezkeszám $\leq 100 \times 10^{9} / 1$ vagy DIC-nek megfelelő alvadási paraméterek (spontán prolongált alvadási idők, alacsony fibrinogénszint, magas D-dimer-szint)

Generalizált bőrkiütés Erythemás, apró, konfluációs hajlamot mutató, nem viszkető, nem fájdalmas maculák. A túlélőkben később tenyéri-talpi hámlás jöhet létre

Lágyszöveti nekrózis Lividen diszkolorált, bullosus vagy nonbullosus elhalás

\begin{tabular}{ll}
\hline II. Laborkritérium & \\
\hline $\begin{array}{l}\text { Streptococcus pyogenes } \\
\text { izolálása }\end{array}$ & $\begin{array}{l}\text { Steril vagy nem steril helyról származó } \\
\text { klinikai mintából }\end{array}$ \\
\hline
\end{tabular}

\begin{tabular}{ll}
\hline & Esetklasszifikáció $(\mathrm{CDC}, 2010)$ \\
\hline Valószínú & $\begin{array}{l}\text { A fenti kritériumok alapján a klinikai } \\
\text { esetdefiníció teljesül, az eltérések hátteré- } \\
\text { ben más etiológia nem igazolódik, és } \\
\text { fiziológiásan nem steril helyról származó } \\
\text { klinikai mintából } S \text {. pyogenes izolálható }\end{array}$ \\
\hline Igazolt & $\begin{array}{l}\text { A fenti kritériumok alapján a klinikai } \\
\text { esetdefiníció teljesül, az eltérések hátteré- } \\
\text { ben más etiológia nem igazolódik, és } \\
\text { fiziológiásan steril helyról származó klinikai } \\
\text { mintából } S \text {. pyogenes izolálható }\end{array}$
\end{tabular}

CDC = amerikai Járványügyi és Betegségmegelőzési Központ; DIC = disszeminált intravascularis coagulatio; GOT = glutamát-oxálacetáttranszamináz; GPT = glutamát-piruvát-transzamináz; NSAID = nemszteroid gyulladáscsökkentő gyógyszer; STSS = streptococcalis toxikus sokk szindróma belül pozitívvá válnak. A gyorsdiagnosztikát a fertőzési kapuból vagy intraoperatíven, mélyszöveti mintából, vagy gennyből készített kenet Gram szerinti festése és értékelése segítheti elő [9].

A STSS-re jellemző laboratóriumi eltérések - ahogy esetünkben is láthattuk - a klinikai stádiumtól függően alakulnak. A kezdeti fázist balra tolt leukocytosis és hemokoncentráció jellemzi, korai jel a folyadékvesztéshez képest aránytalanul nagy mértékú azotaemia. A folyamat elórehaladásával leukothrombopenia és anaemia, a gyulladásos paraméterek (CRP, prokalcitonin) és a szövetszétesést jelző nekroenzimek (CK, LDH, GOT) extrém emelkedése detektálható. A reaktív hypocalcaemiát a szövetekből felszabaduló és a keringésbe kerülő foszfáttúlsúly magyarázza. Előrehaladó szervi hipoperfúziót jelez a laktátacidózis. A coagulopathia disszeminált intravascularis coagulatiónak (disseminated intravascular coagulation, DIC) felel meg (megnyúlt spontán alvadási idők, alacsony fibrinogénszint). A fertőzés klinikai fókuszának bizonyítására, illetve a lágyrész-gyulladás eredetére a MR és a CT az első́ként választandó képalkotó modalitások. Bôr-lágyrész eredetû́ infekció kiterjedtségének, mélységének vizsgálatára - különösképpen nekrotizáló fasciitis esetén - a MR szenzitívebb, de aspecifikusabb, mint a CT. Fasciitisre pathognomicus radiomorfológiai eltérés lehet zsírelnyomásos, $\mathrm{T}_{2}$-súlyozott $\mathrm{MR}$-felvételen a megvastagodott, hiperintenzív fascia [10]. A lágyrészultrahang előnye a CT/MR-rel szemben, hogy ágy mellett is elvégezhető, és korlátlanul ismételhető. Hátránya, hogy kevéssé szenzitív, és gyenge prediktív értékú a mélységi kiterjedésre nézve. A túl korán készített képalkotó vizsgálatok valamennyi modalitás esetén fals negatívak lehetnek. Fontos megjegyezni, hogy instabil beteg esetén, amennyiben a fizikális vizsgálat, a laboreltérések és a radiológiai eredmények nem egybehangzóak, a sebészeti intervenciónak késlekedés nélkül meg kell történnie, akár az elváltozás látványa alapján. Ezen esetekben a mútéti exploráció egyszerre diagnosztikus és terápiás értékü [3].

\section{A STSS terápiája}

A STSS rossz prognózisát a klinikumra és a laboreltérésekre alapozott korai gyanú javíthatja. A betegség ellátása interdiszciplináris, sürgősségi és intenzív terápiás orvosok, sebészek, radiológusok, infektológusok és mikrobiológusok részvételével. Korai gyanú esetén azonnal nagy volumenú krisztalloidoldat pótlását kell megkezdeni $(25-30 \mathrm{ml} / \mathrm{ttkg} / \mathrm{h})$. A specifikus terápia pilléreit a hatékony antistreptococcalis antibiotikum indítása mellett a rapid góctalanítás (klinikaliag igazolható fókusz jelenlétében), illetve a sokszervi elégtelenség jeleit mutató beteg intenzív osztályra történő korai átvétele, monitorizálása és szupportációja adja.

Napjainkban valamennyi $S$. pyogenes-izolátum in vitro teljes penicillinérzékenységet mutat, a STSS első vonalbeli antibiotikumterápiája így intravénás (iv.) penicillin 
G, javasolt dózisa 4 millió nemzetközi egység (NE) 4 óránként (vagyis 24 millió NE/nap). Penicillin G elérhetetlensége esetén iv. ampicillin is adható $4 \times 3 \mathrm{~g}$ dózisban. A $S$. pyogenes nem termel béta-laktamázt, ezért enzimgátlót is tartalmazó béta-laktám-gyógyszerkombináció (például amoxicillin-klavulánsav, ampicillin-szulbaktám stb.) adása nem indokolt (és káros is lehet). Amennyiben a klinikum alapján a kórképet nem lehet a $S$. aureus okozta TSS-tól elkülöníteni, a mikrobiológiai leletek beérkeztéig iv. cefazolin adása javasolt $3 \times 2 \mathrm{~g}$ dózisban. A béta-laktám antibiotikummal kombinációban $3 \times 900 \mathrm{mg}$ dózisban iv. klindamicint szükséges indítani. A klindamicin feltehetően gátolja a bakteriális fehérje- (így: toxin)termelést, addicionális hatékonyságát állatmodellekben és klinikai vizsgálatokban is igazolták $[11,12]$. Szerepe fontos még a bakteriális inoculumeffektusnak, vagyis a béta-laktámok nagy koncentrációjú, ritkán osztódó baktérium jelenlétében megfigyelhető relatív hatáscsökkenésének áttörésében (fóleg nekrotizáló lágyrész-infekciók esetén). Az antibiotikumterápia optimális időtartama kérdéses, kevés evidencia szól a legtöbbször alkalmazott 14 napos kezelés mellett. A terápia hosszának meghatározásában valószínúleg fontosabb szerepe van a reoperációk szükségességének, valamint a folyamatos klinikai újraértékelésnek és a stabilitás elérésének.

A terápia második pillérét a korai és agresszív sebészi ellátás jelenti, mely nekrotizáló fasciitis vagy myositis esetén elősegíti a sokkos beteg stabilizálását, és megmentheti az érintett végtag és a beteg életét. Hangsúlyozzuk, hogy az antibiotikumterápia önmagában kevés a STSS meggyógyítására, mivel az antibiotikumok penetrációja az avascularis szöveti nekrózisba elégtelen. A sebészi feltárás diagnosztikus jelentőségét az adja, hogy a mélyszöveti és fasciaérintettség vizuálisan kontrollálható, és pozitivitás esetén nagy mennyiségű mikrobiológiai és hisztopatológiai minta nyerhető. A sebészi feltárás egyúttal terápiás is, hiszen a fasciaterek megnyitásával a mélyszövetek nyomása csökkenthető, a fascia alatti izmok életképessége ellenőrizhető, és a devitalizált szövetek széles szegéllyel eltávolíthatók. Az esetek jelentős hányadában további reoperáció(k)ra kerülhet sor [3]. A sokszervi elégtelenség kontrolljának másik klinikai eszköze a korai intenzív terápiás konzílium és áthelyezés. A sokkos beteg ellátása során invazív hemodinamikai monitorizálás, vazopresszor- és inotrop szupportáció, gépi lélegeztetés és vesepótló kezelés válhat szükségessé $[7,13]$.

Bár ismert, hogy a streptococcalis M-proteinek és exotoxinok ellen termelt neutralizáló antitestek alacsony titerü jelenléte az invazív $S$. pyogenes-betegség gyakoribb előfordulásával korrelál, az intravénás immunglobulin (IVIG) adjuváns pótlása STSS-ben nem hozta meg a várt terápiás áttörést [14]. Két randomizált, placebokontrollált, kettős vak klinikai vizsgálat eredményei alapján felmerült, hogy az IVIG-et kapó betegek kis hányadánál a sokszervi elégtelenség gyorsabban szűnik, azonban egy- értelmű túlélési előny vagy hosszú távú funkcionális statusjavulás nem volt igazolható $[15,16]$. Az Infectious Diseases Society of America (IDSA) ajánlása alapján további vizsgálatok szükségesek az IVIG hatékonyságának igazolására ebben az indikációban [17]. Ezek alapján STSS-ben jelenleg az IVIG rutinszerü alkalmazása nem ajánlható, de súlyos állapotú betegeknek esetileg adjuvánsként adható.

Összefoglalva: A STSS magas arányú morbiditásán és mortalitásán sebészileg eradikálható góc esetén a beavatkozás azonnali elvégzése, a maximális dózisú kombinált parenteralis antibiotikumterápia és intenzív osztályos ellátás javíthat.

\section{A STSS prognózisa és prevenciója}

A STSS rövid és hosszú távú prognózisa - az invazív $S$. pyogenes-betegségen belül - kifejezetten rossz. Irodalmi adatok alapján az adekvát és gyors ellátás ellenére a kórházi mortalitás 30-70\% körül is mozoghat. A korai halálozás legfőbb rizikófaktorai: a beteg életkora, komorbiditásainak száma és súlyossága, a lágyrész-nekrózis mélysége/kiterjedtsége, valamint a diagnózisig eltelt idő. A betegség kritikus szakaszát túléltek körében az amputáció és a lágyrész-deficitek ellátását célzó további rekonstruktív beavatkozások jelentenek súlyos betegségterhet. Késői szövődményként számíthatunk a veseelégtelenség fixációjára, a cardialis és a légzési status további romlására is [18].

A $S$. pyogenes ellen vakcinát egyelőre nem sikerült kifejleszteni. Mivel az indexesettel egy háztartásban élő kontaktjai körében a szekunder fellépő betegség rizikója több százszoros az átlagpopulációhoz viszonyítva, bizonyos személyek posztexpozíciós kemoprofilaxisban részesíthetők, az eljárás hatékonysága azonban kérdéses. A CDC ajánlása szerint a kontaktust követő 7 napon belül kemoprofilaxis adható az indexbeteggel a STSS kezdete elött 7, illetve az effektív antibiotikumterápia megkezdését követő 1 nappal, minimum 24 órája egy háztartásban tartózkodó magas rizikójú kontaktszemélyeknek. Egészségügyi dolgozó akkor tekinthető kontaktnak, ha a hatékony antibiotikumterápia indítása előtti 24 órában a beteg légúti váladékával magas rizikójú expozíciója történt (endotrachealis intubáció, légúti szekrétum leszívása). Más közeli kontaktok (például kollégiumi szobatárs) körében profilaxis adása nem, csak 30 napos tünetobszerváció szükséges. Felnőtteknél orális kemoprofilaxisra használható penicillin V (napi $4 \times 250$ $\mathrm{mg}$ ) vagy cefalexin (napi $2 \times 1 \mathrm{~g}$ ), ismert allergia esetén pedig klindamicin (napi $3 \times 900 \mathrm{mg}$ ) 10 napig [19].

\section{Következtetés}

A streptococcalis toxikus sokk szindróma (STSS) jellemzően a Streptococcus pyogenes szuperantigénjei és toxinjai által okozott hiperakut, életet veszélyeztető többszervi érintettséggel járó betegség. Eredményes terápiájának 
alapját a korai felismerés adja: a lázzal, lágyrész-fájdalommal, scarlatiniform kiütéssel (erythroderma) járó progresszív légzési-keringési elégtelenség hátterében mindig merüljön fel a TSS lehetősége is. Amennyiben klinikai vagy képalkotó vizsgálattal behatolási kapu és fertőzéses góc igazolódik, a haladéktalan sebészi beavatkozás elengedhetetlen a túlélés esélyének növeléséhez. Az intenzív osztályos támogató kezelés után a kezelés harmadik pillére a hatékony antibiotikumterápia bevezetése, esetleg intravénás immunglobulin-kiegészítéssel. A kórkép mortalitása még gyors klinikai és intenzív terápiás intervenció esetén is $30-70 \%$ közötti; a túlélők körében a maradványtünetek súlyosak lehetnek.

Anyagi támogatás: Sz. B. G.: Az EFOP-3.6.3-VEKOP16-2017-00009 jelzésű Kiegészítő Kutatási Kiválósági PhD Ösztöndíjban, valamint az NTP-NFTÖ-B-18 jelzésû Nemzet Fiatal Tehetségeiért Ösztöndíjban részesült. Az ösztöndíjakat megítélő szervek az eset kiválasztásában, a kézirat előkészítésében és beküldésében semmilyen formában nem vettek részt.

Szerzői munkamegosztás: Sz. B. G.: Az eset prezentációja, irodalmazás, az összefoglaló szövegezése. K. R.: Nyelvi lektorálás, irodalmazás, az összefoglaló szövegezése. L. K. Sz.: Nyelvi lektorálás, irodalmazás. N. R.: A kórokozó izolálása és azonosítása. K. B.: Szakmai és nyelvi lektorálás, az összefoglaló szövegezése, a kézirat szerkesztése. A cikk végleges változatát valamennyi szerző elolvasta és jóváhagyta.

Érdekeltségek: A szerzőknek nincsenek érdekeltségeik.

\section{Irodalom}

[1] National Public Health and Medical Officer Service. Reported infectious diseases in Hungary, 2014-2018. [Nemzeti Népegészségügyi Központ. Bejelentett fertőző megbetegedések Magyarországon, 2014-2018.] Available from: www.antsz.hu/ data/cms92714/Fertozo_2018.pdf [accessed: July 10, 2019]. [Hungarian]

[2] Cone LA, Woodard DR, Schlievert PM, et al. Clinical and bacteriologic observations of a toxic shock-like syndrome due to Streptococcus pyogenes. N Engl J Med. 1987; 317: 146-149.

[3] Schmitz M, Roux X, Huttner B, et al. Streptococcal toxic shock syndrome in the intensive care unit. Ann Intensive Care 2018; 8: 88 .

[4] Lamagni TL, Efstratiou A, Vuopio-Varkila J, et al. The epidemiology of severe Streptococcus pyogenes associated disease in $\mathrm{Eu}-$ rope. Euro Surveill. 2005; 10: 179-184.
[5] Lamagni TL, Darenberg J, Luca-Harari B, et al. Epidemiology of severe Streptococcus pyogenes disease in Europe. J Clin Microbiol. 2008; 46: 2359-2367.

[6] Bryant AE, Bayer CR, Aldape MJ, et al. The roles of injury and nonsteroidal anti-inflammatory drugs in the development and outcomes of severe group A streptococcal soft tissue infections. Curr Opin Infect Dis. 2015; 28: 231-239.

[7] Stevens DL, Bryant AE. Severe group A streptococcal infections. In: Ferretti JJ, Stevens DL, Fischetti VA (eds.) Streptococcus pyogenes: basic biology to clinical manifestations. University of Oklahoma Health Sciences Center, Oklahoma City, OK, 2016; pp. 661-665.

[8] Kaul R, McGeer A, Low DE, et al. Population-based surveillance for group A streptococcal necrotizing fasciitis: clinical features, prognostic indicators, and microbiologic analysis of seventy-seven cases. Am J Med. 1997; 103: 18-24.

[9] CDC. Streptococcal Toxic Shock Syndrome (STSS) (Streptococcus pyogenes) - 2010 Case Definition. Centers for Disease Control and Prevention, Atlanta, GA. Available from: http://www. cdc.gov/nndss/conditions/streptococcal-toxic-shock-syndrome/case-definition/2010 [accessed: July 10, 2019].

[10] Ali SZ, Srinivasan S, Peh WC. MRI in necrotizing fasciitis of the extremities. Br J Radiol. 2014; 87: 20130560.

[11] Sriskandan S, McKee A, Hall L, et al. Comparative effects of clindamycin and ampicillin on superantigenic activity of Streptococcus pyogenes. J Antimicrob Chemother. 1997; 40: 275-277.

[12] Carapetis JR, Jacoby P, Carville K, et al. Effectiveness of clindamycin and intravenous immunoglobulin, and risk of disease in contacts, in invasive group A streptococcal infections. Clin Infect Dis. 2014; 59: 358-365.

[13] Rhodes A, Evans LE, Alhazzani W, et al. Surviving sepsis campaign: international guidelines for management of sepsis and septic shock: 2016. Intensive Care Med. 2017; 43: 304-377.

[14] Basma H, Norrby-Teglund A, Guedez Y, et al. Risk factors in the pathogenesis of invasive group A streptococcal infections: role of protective humoral immunity. Infect Immun. 1999; 67: 18711877.

[15] Darenberg J, Ihendyane N, Sjölin J, et al. Intravenous immunoglobulin G therapy in streptococcal toxic shock syndrome: a European randomized, double-blind, placebo-controlled trial. Clin Infect Dis. 2003; 37: 333-340.

[16] Madsen MB, Hjortrup PB, Hansen MB, et al. Immunoglobulin $\mathrm{G}$ for patients with necrotising soft tissue infection (INSTINCT): a randomised, blinded, placebo-controlled trial. Intensive Care Med. 2017; 43: 1585-1593.

[17] Stevens DL, Bisno AL, Chambers HF, et al. Practice guidelines for the diagnosis and management of skin and soft tissue infections: 2014 update by the Infectious Diseases Society of America. Clin Infect Dis. 2014; 59: 147-159.

[18] Breiman RF, Davis JP, Facklam RR, et al. Defining the group A streptococcal toxic shock syndrome. Rationale and consensus definition. JAMA 1993; 269: 390-391.

[19] Robinson KA, Rothrock G, Phan Q, et al. Risk for severe group A streptococcal disease among patients' household contacts. Emerg Infect Dis. 2003; 9: 443-447.

(Szabó Bálint Gergely dr., Budapest, Albert Flórián út 5-7., 1097 e-mail: szabo.balint.gergely@gmail.com)

A cikk a Creative Commons Attribution 4.0 International License (https://creativecommons.org/licenses/by/4.0/) feltételei szerint publikált Open Access közlemény, melynek szellemében a cikk bármilyen médiumban szabadon felhasználható, megosztható és újraközölhetö, feltéve, hogy az eredeti szerző és a közlés helye, illetve a CC License linkje és az esetlegesen végrehajtott módositások feltüntetésre kerülnek. (SID_1) 